\title{
Sorting models of household location and urban amenities
}

van Duijn, Mark; MöhImann, Jan; Mulalic, Ismir; Rouwendal, Jan

Published in:

Skills and Cities: Implications of location preferences of highly educated workers for spatial development of metropolitan areas

Publication date:

2016

Document Version

Publisher's PDF, also known as Version of record

Link back to DTU Orbit

Citation $(A P A)$ :

van Duijn, M., Möhlmann, J., Mulalic, I., \& Rouwendal, J. (2016). Sorting models of household location and urban amenities. In S. Musterd, M. Bontje, \& J. Rouwendal (Eds.), Skills and Cities: Implications of location preferences of highly educated workers for spatial development of metropolitan areas (pp. 86-116). Routledge.

\section{General rights}

Copyright and moral rights for the publications made accessible in the public portal are retained by the authors and/or other copyright owners and it is a condition of accessing publications that users recognise and abide by the legal requirements associated with these rights.

- Users may download and print one copy of any publication from the public portal for the purpose of private study or research.

- You may not further distribute the material or use it for any profit-making activity or commercial gain

- You may freely distribute the URL identifying the publication in the public portal 


\section{Skills and Cities}

Implications of location preferences

of highly educated workers for spatial development of metropolitan areas

Edited by Sako Musterd, Marco Bontje and Jan Rouwendal 


\section{Contents}

List of figures $\quad$ xvii

List of tables $\quad$ xix

List of contributors $\quad \mathrm{xxii}$

Acknowledgements xxiii

\section{PART I}

1 Skills and cities: an introductory framework

SAKO MUSTERD, MARCO BONTJE AND JAN ROUWENDAL

2 Housing and amenities as attracting factors for cities and their regions: a literature review

BART SLEUTJES

3 Residential sorting of creative knowledge workers in four European knowledge cities

BART SLEUTJES

\section{PART II}

4 Housing and location preferences of higher educated workers in the Netherlands: an introduction

MARCO BONTJE, SAKO MUSTERD, AND JAN ROUWENDAL

5 'The' creative class does not exist: contrasting the residential preferences of creative and technical workers in Amsterdam and Eindhoven 
xvi Contents

6 Sorting models of household location and urban amenities 86

MARK VAN DUIJN, JAN MÖHLMANN, ISMIR MULALIC AND

JAN ROUWENDAL

7 Integration and policy simulations

JASPER DEKKERS, JAN MÖHLMANN AND JAN ROUWENDAL

\section{PART III}

8 Housing and location preferences of higher educated international migrants in the Netherlands: an introduction

JAN ROUWENDAL, SAKO MUSTERD AND MARCO BONTJE

9 Stated residential preferences of highly skilled international migrants

BART SLEUTJES AND WILLEM R. BOTERMAN

10 International students and the Netherlands

OR LEVKOVICH, JAN ROUWENDAL AND CARLA SÁ

11 Location choices of highly educated foreign workers:

the importance of urban amenities

OR LEVKOVICH AND JAN ROUWENDAL

12 Revealed residential preference of international migrants working in creative and knowledge intensive industries: the settlement process

BART SLEUTJES AND SAKO MUSTERD

\section{PART IV}

13 Skills and cities: jobs and amenities

SAKO MUSTERD, MARCO BONTJE AND JAN ROUWENDAL

Index 